\title{
WORKED EXAMPLE USING ILL-STRUCTURED PROBLEM: TRAINED HIGH ORDER THINKING SKILL
}

\author{
Atik Rodiawati \\ Department of Mathematics Education, Universitas Negeri Yogyakarta \\ E-mail: atikrodiawati.2017@student.uny.ac.id
}

Received 26 June 2018; Received in revised form 17 September 2018; Accepted 26 September 2018

\begin{abstract}
Cognitive Load Theory (CLT) is design theory instructional that uses human cognitive architecture. One of the cognitive load theory types is worked example. This study aims to analyze theoretically the ability of worked example using ill-structured problem in training high order thinking skill. This article is designed by reviewing literatures of worked example, ill-structured problem, and high order thinking skill; arranging them to get their primary relation; finally concluding the aim of this study. The main relation of them is one characteristic of high order thinking skill is ill-structured and challenging problems. The result of this research shows theoretically that worked example using ill-structured problems can train high order thinking skill. It is caused by worked example which contains ill-structured problems can train students to analyze and evaluate problem solving through examples without high cognitive load, so that students obtain ill-structured problems solving strategy. Furthermore, giving a wider problem to students' practice as a follow-up action from worked example will train students to create innovative solutions to wider problems.
\end{abstract}

Keywords: High Order Thinking Skill; Ill-Structured Problem; Worked Example

\section{INTRODUCTION}

Cognitive Load Theory contributes to the development of education by keeping learners cognitive architecture (Chinnappan, 2010; Sweller, Ayres, \& Kalyuga, 2011). One type of cognitive load theory that has good influence on learning is worked example. The worked example provides the learners with information about the solution of the problem. Theoretically, the worked example can assist students in solving problem through the formation of problem solving schemes that are stored on long term memory (Sweller et al., 2011). Empirically, some studies have found out that the learner given worked example and followed by solving a problem can solve the problem better than the learner who asked to solve the problem directly without worked example (Pillay, 1994; Retnowati, Ayres, \& Sweller, 2010; Sweller \& Cooper, 1985). This is because it is closely related to the cognitive load that students get to solve a problem.

However, the development of a theory is necessarily followed by the weakness of the theory, without exception for the worked example itself. A study by Sweller \& Cooper (1985) found that the worked example was better in helping students to solve the problem when compared with without worked example, but this study found a problem that the worked example can't be used for the wider problem than example problem given. However, this problem found a solution through the research of Cooper \& Sweller (1987), Pillay (1994) and Retnowati et al. (2010). Sweller and Cooper concluded that the worked example can be used for expansion of the problem but it takes extra time and requires automation of the operator in solving the problem. Pillay found that the worked example could be used for the expansion of the problem and worked example outperformed the problem solving

\section{8 | AKSIOMA}

Jurnal Pendidikan Matematika FKIP Univ. Muhammadiyah Metro 
especially for two-and threedimensional mental rotation problems. Retnowati, Ayres and Sweller produced that the worked example has a significant advantage both for a problem similar to that of the sample although the wider problem of the example.

In addition, the worked example in its development is considered only in accordance with the scope of wellstructured domain material or in solving the problem using clear algorithms such as mathematics and science (Renkl, A., 2005). However, several studies have proved that the worked example is not only appropriate for well-structured domains, but also suitable for the scope of unstructured material in its completion or ill-structured domain (Oksa, Kalyuga, \& Chandler, 2010; Rourke \& Sweller, 2009). Whereas, mathematics that considered as wellstructured domain whether it would be only composed of well-structured problems without ill-structured problems. Furthermore, if math has an ill-structured problem whether the illstructured problem in mathematics can be solved with existence of worked example. This will be one of the focus of the study in this article.

Worked example is an approach that pays attention on cognitive architecture of learners by focusing on minimizing the cognitive load of learners. The focus on minimizing cognitive loads allows this approach to be considered to only guide students to follow the patterns and procedures without involving the thinking process of learners, especially high order thinking. It will also be the focus of the study in this article.

This article is compiled by reviewing the literature relating to the worked example with the aim of looking at the capabilities of worked example in solving ill-structured problems theoretically. In addition, this article also examines the literature related to high order thinking which aims to find theoretically a form of worked example that can facilitate the thinking process of learners, especially for high order thinking. Thus, this article is expected to be one of the theoretical references as a basis for developing a worked example that is oriented to high order thinking skills.

\section{DISCUSSION}

Its part consists of the explanation of worked example, high order thinking skill, ill-structured problem, result and discussion.

\section{Worked Example}

Worked example can be interpreted as learning from example. Worked example contains solutions to problems (Sweller et al., 2011). The effect of a worked example can be wellknown in learning when learners solve advanced problems rather than learners solving problems similar to examples (Sweller et al., 2011). Worked example helps learners in solving problems by minimizing students' cognitive load. It can happen because through the worked example presented, the students can recognize the problem solving scheme and store it in long term memory, so it can be used when solving related problems or advanced problems. Worked example contains problem statement and strategy to solve it. So, what is expected is that students can learn the key to solve the problem and use it to solve other problems (Sweller et al., 2011). Mayer in Retnowati (2006) says that the worked example contains problem statements, solutions and comments in the solution that make the worked example superior in solving the problem. 
The learning stage of worked example consists of four steps adapted from Retnowati et al., (2010), namely:

1. Revision Phase

At this stage, each student is given a sheet containing some of the main material of the problem to be solved later. For example, students will learn problem solving on lines and angles, so at this stage students are given a portion of a set of corner theorems, angular rules, the relationship between lines and angles they have learned before. At this stage the teacher also gives an explanation of the main material and explains an example of a working example. Then the students individually pay attention to the pairs of each major material with the worked examples given to know the key strategy to solve the given problem. Furthermore, students solve similar problems with the worked example given.

2. The Group Skills Induction Stage

At this stage, students are asked to work in small groups with due attention to the proportional abilities of students. Each group will be given some of the primary material of the problem that will be solved later to complement some of the primary material given in the previous stage. Basically, this stage is the same as the previous stage only the main material characteristics at this stage are more difficult and students learn and solve problems given in groups.

3. Acquisition Step

At this stage, students are given further or wider problems of problems than the worked example. The purpose of this stage is students have experience in solving problems related to the material being discussed but in broader questions.

4. Test Phase

At this stage, students are given several problems to be solved individually. This stage aims to assess students' abilities according to the learning objectives

\section{High Order Thinking Skill}

High order thinking skill is one of the most demanding capabilities of today. It is because this era wants people who are productive in analyzing the needs and able to innovate. In accordance with the ability of this high order thinking skill emphasizes on analysis, evaluation and creation.

Following are is the definition of high order thinking by some experts

Table 1. Some definition of high order thinking (Goethals, 2013)

\begin{tabular}{|c|c|c|}
\hline Source & Year & Definition \\
\hline King et al. & 1998 & $\begin{array}{l}\text { "(It) includes critical, logical, reflective, metacognitive, and } \\
\text { creative thinking. (It is) activated when individuals encounter } \\
\text { unfamiliar problems, uncertainties, questions, or dilemmas." }\end{array}$ \\
\hline NCTM & 2000 & "Solving a routine problem." \\
\hline $\begin{array}{l}\text { Anderson and } \\
\text { Krathwohl }\end{array}$ & 2001 & The processes - analyze, evaluate, and create. \\
\hline $\begin{array}{l}\text { Lopez and } \\
\text { Whittington } \\
\text { Weiss, }\end{array}$ & 2001 & $\begin{array}{l}\text { "(It) occurs when a person takes new information and } \\
\text { information stored in memory and interrelates and/or rearranges } \\
\text { and extends this information to achieve a purpose or find } \\
\text { possible answers in perplexing situations." }\end{array}$ \\
\hline Weiss, E. & 2003 & $\begin{array}{l}\text { Collaborative, authentic, ill-structured, and challenging } \\
\text { problems. }\end{array}$ \\
\hline
\end{tabular}




\begin{tabular}{|l|l|l|}
\hline Miri et al. & 2007 & $\begin{array}{l}\text { "... the strategy - the setting of meta-objectives; whereas } \\
\text { critical, systemic, and creative thinking are the tactics - the } \\
\text { activities needed to achieve the proclaimed objectives." }\end{array}$ \\
\hline Rajendran, N & 2008 & The expanded use of the mind to meet new challenges. \\
\hline Thompson, T. & 2008 & "Non-algorithmic thinking." \\
\hline $\begin{array}{l}\text { Thomas, A. } \\
\text { and Thorne, }\end{array}$ & 2010 & $\begin{array}{l}\text { "... (it) takes thinking to higher levels than just restating the } \\
\text { facts. (It) requires that we do something with the facts. We must } \\
\text { understand them, connect them to each other, categorize them, } \\
\text { manipulate them, put them together in new or novel ways, and } \\
\text { apply them as we seek new solutions to new problems." }\end{array}$ \\
\hline $\begin{array}{l}\text { G. Kruger, K. } \\
\text { Year }\end{array}$ & 2013 & $\begin{array}{l}\text { It involves "concept formation, critical thinking, } \\
\text { creativity/brainstorming, problem solving, mental } \\
\text { representation, rule use, reasoning, and logical thinking." }\end{array}$ \\
\hline
\end{tabular}

Ill-Structured Problem

Ill-structured problem is usually in a particular context. In the case of illstructured problems, one or more aspects of the problem are not provided, the description of the problem is unclear or not well defined, and the information needed to solve the problem is not contained in the problem statement (Chi, Feltovich, \& Glaser, 1981 in Jonassen (1997)). Structured problems are the kinds of problems encountered in the everyday context, so there usually appears to be gaps, called problems. Because the problem raised is a daily problem, the solution of the problem can't be predicted directly and the solution is generally not convergent. Solution problems sometimes require integration of various concepts.

Ill-structured problems also require students to express their own opinions or beliefs about the issues expressed, thus solving the problem is an activity that values the uniqueness of each individual (Meacham \& Emont in Jonassen (1997)).So the solution of illstructured problems asks students to justify and provide logical reasons to support their justification.

\section{Result and Discussion}

One focus of the study in this article is mathematics that considered as well-structured domain whether it would be only composed of wellstructured problems without illstructured problems. By definition, illstructured problem is a matter of daily life with the characteristics of the problem that is not clearly defined and demands the integration of some concepts in its solution. Thus, based on this definition, mathematics certainly also contains ill-structured problems in addition to well-structured problems because mathematics also contains a matter of contextual and realistic. Solving math problems sometimes also requires students to integrate concepts.

Furthermore, if math has an illstructured problem whether the illstructured problem in mathematics can be solved with existence of worked example. By definition, the worked example is a statement of the problem and followed by its completion. Sweller et al., (2011) revealed that in the worked example, students can learn the key strategy of problem solving and use the strategy to solve other problems. So if the problem is classified as an illstructured problem that in fact does not have a specific algorithm in its completion, it can still be given through the worked example because the worked example given not only focus on the algorithm but also the strategy of completion. 
Worked example can depress the cognitive load of learners. If the learner is given a problem that they need to solve directly without any help, it will increase the load in their brain capacity. Therefore, there are worked examples to help minimize the situation. However, the assistance provided to learners is not expected to make them unwilling to think because solving the problem only by following the existing settlement procedures. Thus, if worked example uses problems that contain not only algorithms in its completion, it will train students' thinking skills, especially if the problem is an ill-structured problem. By definition, Weiss E in (Goethals, 2013) that ill-structured and challenging problems are the definition of higher order thinking. In addition, the example of completion in the worked example can encourage students to analyze the steps or completion strategies provided, as well as in the assessment phase (test phase) in the worked example can train the students to make the innovation of the solution because the given problem is ill-structure problem. It is in line with Anderson and Krathwohl's definition of higher order thinking in (Goethals, 2013) i.e. higher order thinking is "The processes - analyze, evaluate, and create". Thus, worked examples using ill-structured problems can minimize students' cognitive loads as well as train students for higher-order thinking.

However, worked examples using ill-structured problems in training students' high order thinking have their own challenges. The challenge is related to the revision phase. Since the use of concepts in the settlement of illstructured problems is not certain in the material being studied, the student must really have good concept on the previous material. So, having good concept in previous material is required for students.

\section{CONCLUSION AND RECOMMENDATION}

Based on the above description, it can be concluded that the worked example using ill-structured problem can train students' high order thinking skill. It is because through a worked example, students are assisted to minimize their cognitive load and students are given a chance to solve wider problem than example problem. It's also because through ill-structured problems, students are trained to analyze and evaluate problem-solving in the worked example, and are trained to create innovative solutions to other wider issues. So, training students' high order thinking skill through worked example will work optimally if teacher can choose the appropriated problem, for example ill-structured problem.

The suggestion that can be given from this literature review is this study can serve as a theoretical basis for conducting advanced research or experimenting learning with a working example using ill-structured problems. In addition, it is important to notice that when a teacher wants to practice student's high-order thinking skills, the teacher must be good at choosing related problems, one of the types of problems that can be given is the illstructured problem.

\section{REFERENCESS}

Chinnappan, M. (2010). Cognitive Load and Modelling of an Algebra Problem. Mathematics Education Research Journal, 22(2), 8-23. https://doi.org/10.1007/BF0321756 3

Cooper, G., \& Sweller, J. (1987). Effects of schema acquisition and rule automation on mathematical problem-solving transfer. Journal of Educational Psychology, 79(4),

\section{2 | AKSIOMA}


ISSN 2089-8703 (Print) Vol. 7, No. 2 (2018) 308-313

ISSN 2442-5419 (Online)

$347-362$.

https://doi.org/10.1037/00220663.79.4.347

Goethals, P. L. (2013). The Pursuit of Higher-Order Thinking in the Mathematics Classroom: A Review.

Jonassen, D. H. (1997). Instructional design models for well-structured and III-structured problem-solving learning outcomes. Educational Technology Research and Development, 45(1), 65-94. https://doi.org/10.1007/BF0229961 3

Oksa, A., Kalyuga, S., \& Chandler, P. (2010). Expertise reversal effect in using explanatory notes for readers of Shakespearean text.

Instructional Science, 38(3), 217236.

https://doi.org/10.1007/s11251009-9109-6

Pillay, H. K. (1994). Cognitive Load and Mental Rotation: Structuring Orthographic Projection for Learning and Problem Solving., 91-113. Retrieved from http://ezproxy.lib.ucalgary.ca/login ?url=http://search.ebscohost.com/l ogin.aspx ?direct $=$ true $\& \mathrm{db}=$ eric $\& A$ $\mathrm{N}=\mathrm{EJ}$ 495235\&site $=$ ehost-live

Renkl, A. (2005). The worked-out examples principle in multimedia learning., (May), 229-246.

Retnowati, E. (2006). Worked

Examples in Mathematics 2. Why Learning by Example is Effective : A Cognitive Load Theory, 393395.

Retnowati, E., Ayres, P., \& Sweller, J. (2010). Worked example effects in individual and group work settings. Educational Psychology, 30(3), 349-367.

https://doi.org/10.1080/014434110 03659960

Rourke, A., \& Sweller, J. (2009). The worked-example effect using illdefined problems: Learning to recognise designers' styles.

Learning and Instruction, 19(2), 185-199.

https://doi.org/10.1016/j.learninstr uc. 2008.03 .006

Sweller, J., Ayres, P., \& Kalyuga, S. (2011). Cognitive Load Theory. New York, NY: Springer (Vol. 10). https://doi.org/10.1007/978-14419-8126-4

Sweller, J., \& Cooper, G. A. (1985). The Use of Worked Examples as a Substitute for Problem Solving in Learning Algebra. Cognition and Instruction, 2(1), 59-89. https://doi.org/10.1207/s1532690x ci0201_3 